\title{
SISTEM INFORMASI KEDKLATAN SDM KESEHATAN (SIDIKLAT) PADA CV. UPTD BALAI PELATIHAN KESEHATAN PROVINSI KALIMANTAN TIMUR
}

\author{
Irwan Ukkas $^{1)}$, Jundro Daud ${ }^{2)}$, Sofyan ${ }^{3)}$ \\ ${ }^{1,2}$ Sistem Informasi, Stmik Widya Cipta Dharma \\ ${ }^{3}$ Sistem Informasi, Stmik Widya Cipta Dharma \\ $1,2,3$ Jl. Prof. M. Yamin No. 25, Samarinda, 75123 \\ E-mail : iyan_kasedounk@yahoo.com ${ }^{1)}$, informatikawicida@gmail.com ${ }^{2)}$, bapelkes_bplks@yahoo.co.id ${ }^{3)}$
}

\begin{abstract}
ABSTRAK
UPTD Balai Pelatihan Kesehatan Provinsi Kalimantan Timur adalah merupakan salah satu instansi pemerintah yang bergerak dalam bidang kediklatan kesehatan. Sampai saat ini Kediklatan SDM Kesehatan masih dilakukan dengan cara manual dan menggunakan perangkat komputer dengan pengolahan data laporan menggunakan aplikasi Ms. Excel.

Metode yang digunakan pada penelitian ini meliputi metode pengumpulan data yaitu penelitian lapangan dan penelitian kepustakaan,. Sedangkan metode pengembangan sistem yang digunakan dalam pengembangan sistem informasi ini adalah metode Waterfall terdiri dari Perencanaan sistem, analisis sistem, desain sistem, penerapan sistem, dan perawatan sistem. Dengan bantuan tools seperti Flow on document (FOD), Data Flow document (DFD), Entity Relationship Diagram (ERD), Hiarcycal Input Proses Output (HIPO), struktur database dan desain input output program.

Penelitian ini menghasilkan suatu aplikasi Sistem Informasi Kediklatan SDM Kesehatan (Sidiklat) yang dapat membantu panitia dalam pelakasanaan kegiatan kediklatan SDM kesehatan di UPTD Balai Pelatihan Kesehatan Provinsi Kalimantan Timur.
\end{abstract}

Kata Kunci : Sistem, Informasi, Kediklatan SDM Kesehatan (SIDIKLAT)

\section{PENDAHULUAN}

Sumber Daya Manusia (SDM) Kesehatan untuk penyelenggaraan pelayanan kesehatan secara profesional, bermutu dan terjangkau oleh seluruh masyarakat, memerlukan tenaga kesehatan yang ditugaskan secara penuh untuk melaksanakan kegiatan teknis fungsional. Salah satu tugas teknis fungsional harus mengikuti diklat untuk meningkatkan kopetensi dan wawasan. Sistem Informasi Kediklatan merupakan program yang digunakan dalam proses pelatihan SDM Kesehatan untuk memenuhi kebutuhan data dan informasi kegiatan kediklatan di Unit Pelayanan Tekhnis Daerah (UPTD) Balai Pelatihan Kesehatan.

Pada Unit Pelayanan Tekhnis Daerah (UPTD) Balai Pelatihan Kesehatan Provinsi Kalimantan Timur. dalam pengolahan data pelatihan cendrung mengahadapi masalah dalam pengolahan data mulai dari data peserta sampai dengan pengolahan data sertifikat yang masih menggunakan bantuan Microsoft Word dan Microsoft Excel, dimana proses pengolahan data memerlukan waktu yang lama.

Dalam mengolah data pelatihan SDM Kesehatan pada Unit Pelayanan Tekhnis Daerah (UPTD) Balai Pelatihan Kesehatan Provinsi Kalimantan Timur, sampai saat ini belum didukung oleh tersedianya suatu aplikasi berbasis komputer yang dapat memudahkan dalam pengolahan data sehingga menyebabkan ketidakpraktisan dalam pengelolaan data, keterlambatan penyediaan informasi mengenai proses pelatihan.

Menyadari permasalahan di atas, peneliti memandang perlu untuk menemukan solusi bagi terwujudnya pengelolaan data pelatihan SDM Kesehatan secara mudah dan penyediaan informasi secara cepat, tepat dan akurat serta menghindari masalah akibat kesalahan manusia dengan membuat suatu Sistem Informasi Kediklatan SDM Kesehatan (Sidiklat) pada UPTD Balai Pelatihan Kesehatan Provinsi Kalimantan Timur. Diharapkan sistem ini dapat membantu dalam pengelolaan program pelatihan.

\section{RUANG LINGKUP PENELITIAN}

Berdasarkan rumusan masalah yang telah ada, maka akan dibatasi permasalahan tersebut sebagai berikut :

Tabel Input :

-Input Data Instruktur

-Input Data Diklat

-Input Data Peserta

Proses

-Pelaksanaan Pelatihan

-Penilaian Peserta Pelatihan

-Sertifikat 
Output (keluaran)

-Laporan Daftar Instruktur

-Laporan Daftar Pelatihan

-Laporan Daftar Peserta

-Laporan Pelaksanaan Pelatihan

-Laporan Penilaian Peserta

\section{BAHAN DAN METODE}

\subsection{Penjelasan Bahan}

Sistem merupakan kumpulan elemen yang saling berkaitan yang bertanggungjawab memproses masukan (input) sehingga menghasilkan keluaran (output) (Kusrini, 2007)

Visual Basic selain disebut sebagai bahasa pemrograman (Language Program), juga sering disebut sebagai sarana (Tool) untuk menghasilkan programprogram aplikasi berbasis Windows. (Yuswanto, 2003)

\subsection{Metode}

Model Air Terjun (Waterfall) adalah untuk membantu mengatasi kerumitan yang terjadi akibat proyek-proyek pengembangan perangkat lunak (Simarmata, 2010).

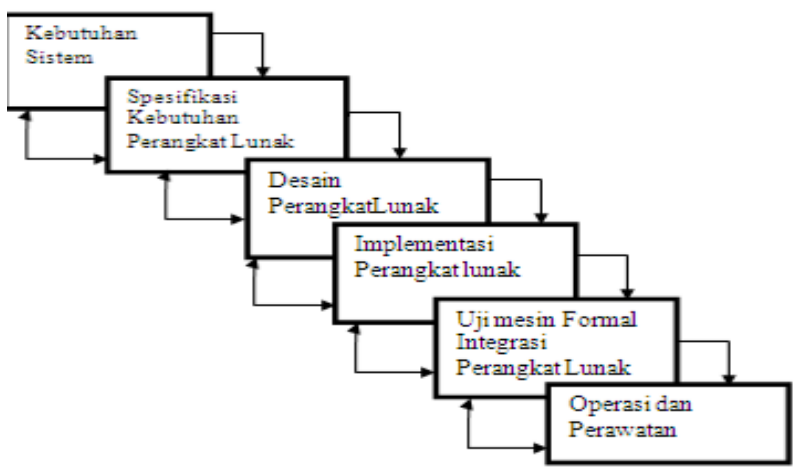

Gambar 1. Model Pengembangan Air Terjun

\section{RANCANGAN SISTEM/APLIKASI}

Flow Of Document ( FOD ) sistem informasi Kediklatan SDM Kesehatan (Sidiklat) pada UPTD Balai Pelatihan Kesehatan Provinsi Kalimantan Timur yang berjalan seperti dapat dilihat pada gambar 4.2 Di mulai dari entitas Panitia memberikan formulir pendaftaran kepada peserta selanjutnya di isi oleh peserta,formulir yang sudah diisi selanjutnya diserahkan kembali kepada panitia. Dari entitas formulir yang telah diisi diproses menjadi peserta diklat. Peserta yang ikut diklat diproses selanjutnya dialirkan dan menjadi laporan daftar peserta penilaian menjadi daftar penilaian diproses menjadi pembuatan laporan nilai. Pada entitas Instruktur/narasumber diproses menjadi data instruktur/narasumber dialirkan dan selanjutnya menjadi proses penilaian, dari daftar instruktur menjadi laporan daftar instruktur/narasumber yang selanjutnya akan diserahkan kepada kepala/pimpinan.

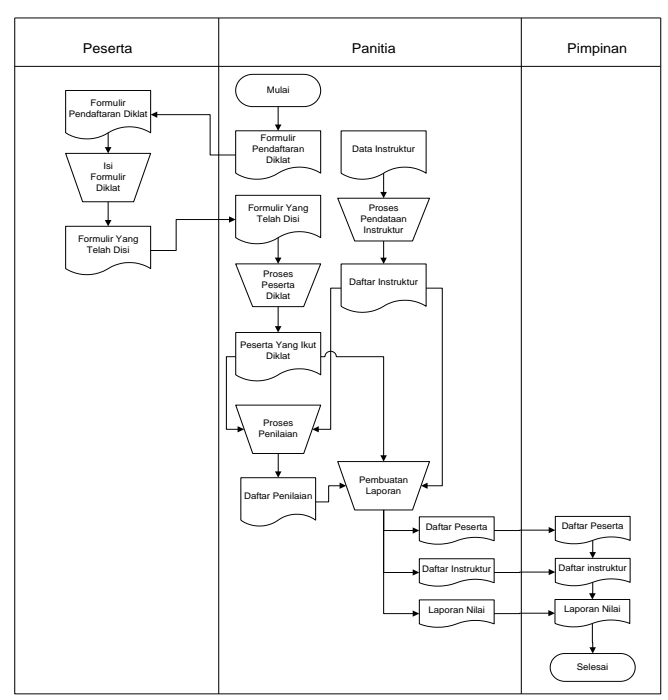

Gambar 2. FOD Yang Berjalan

1. Flow Of Document ( FOD ) sistem informasi kediklatan SDM kesehatan (Sidiklat) pada UPTD Balai Pelatihan Kesehatan Provinsi Kalimantan Timur yang diusulkan seperti dapat dilihat pada gambar 4.3 yang dimulai dari entitas bagian panitia pelatihan kemudian menyerahkan formulir pendaftaran pelatihan yang akan diserahkan kepada peserta untuk kemudian diisi oleh para peserta pelatihan, dari data yang telah diisi kemudian panitia memproses bagian formulir pendaftaran pelatihan. Input data peserta yang selanjutnya masuk didatabase peserta menjadi peserta, selanjutnya diproses menjadi pembuatan laporan dan menjadi laporan daftar peserta pelatihan. Input data diklat yang kemudian menjadi database diklat kemudian diproses menjadi data diklat, kemudian database diklat juga diproses menjadi pelaksanaan pelatihan menjadi data pelaksanaan pelatihan selanjutnya database diklat di alirkan dan diproses menjadi data diklat. Input data instruktur kemudian diproses menjadi daftar instruktur selanjutnya database instruktur dialirkan dan diproses menjadi penilaian, dari database nilai diproses menjadi Proses pembuatan laporan, laporan penilian peserta, daftar peserta, daftar instruktur/pelatih,laporan daftar pelatihan, laporan pelaksanaan pelatihan selanjutnya yang akan diserahkan kepada kepala/pimpinan UPTD Balai Pelatihan Kesehatan Provinsi Kalimantan Timur. 


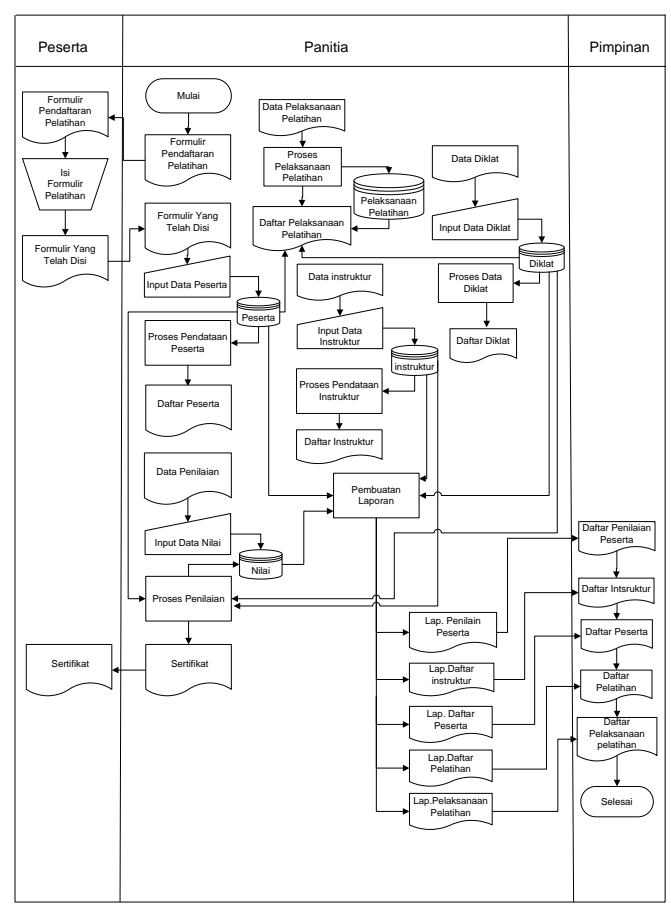

Gambar 3. FOD Yang Diusulkan

\section{1. context Diagram}

Pada gambar 4.4 terdapat 3 (Tiga) entitas, yaitu Entitas bagian panitia memberikan data penilaian peserta kepada sistem, entitas panitia memberikan data instruktur kepada sistem,entitas panitia memberikan data pelaksanaan pelatihan kepada sistem, entitas panitia memberikan data diklat dan entitas panitia mendapat daftar pelatihan dari sistem. Entitas peserta memberikan data peserta kepada sistem selanjutnya sistem memberikan sertifikat kepada peserta. Entitas bagian kepala mendapatkan laporan daftar peserta, laporan daftar instruktur, laporan daftar pelatihan, laporan pelaksanaan pelatihan,laporan penilaian peserta dan entitas peserta mendapat sertifikat dari sistem.

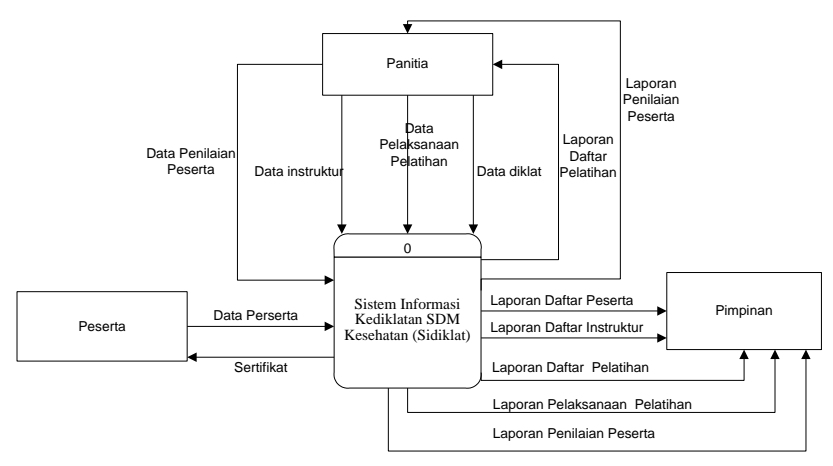

Gambar 4. Context Diagram

\section{Data Flow Diagram (DFD) Level 0}

DFD pada gambar 4.5 Entitas panitia memberikan data diklat dan diproses menjadi diklat, sumber data pembuatan data diklat yang datanya disimpan dalam penyimpanan data (data store) selanjutnya data diklat dialirkan menjadi proses penilain dan proses pelaksanaan pelatihan disimpan dalam penyimpanan data (data store) diproses menjadi laporan selanjutnya dialirkan ke entitas pimpinan. Entitas panitia memberikan data instruktur dan disimpan dalam penyimpanan data (data store) diproses menjadi instruktur. Entitas peserta memberikan data peserta dan diproses menjadi peserta, sumber data pembuatan data peserta yang datanya disimpan dalam penyimpanan data (data store) selanjutnya data peserta di alirkan menjadi proses pelakasanaan pelatihan disimpan dalam penyimpanan data (data store) diproses menjadi pelatihan diproses menjadi laporan selanjutnya dilairkan ke entitas pimpinan. Entitas panitia memberikan data pelakasanaan pelatihan dan diproses menjadi pelaksanaan pelatihan selanjutnya disimpan dalam penyimpanan data (data store) menjadi pelatihan diproses menjadi laporan selanjutnya dilairkan ke entitas pimpinan.

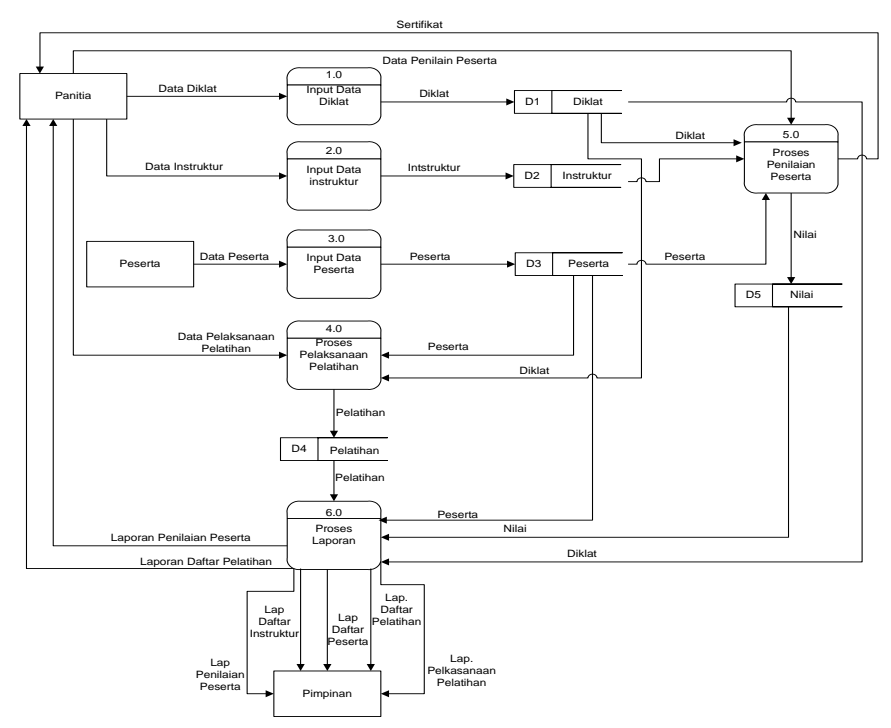

Gambar 5. Data Flow Diagram (DFD) Level 0

3. Data Flow Diagram (DFD) Level 1

DFD pada gambar 4.6 Data store instruktur dialirkan dan diproses menjadi instruktur dan selanjutnya menjadi laporan daftar instruktur selanjutnya di alirkan ke entitas pimpinan /kepala. Data store diklat di prsoses menjadi diklat selanjutnya menjadi laporan daftar pelatihan dan selanjutnya dialirkan ke entitas pimpinan/kepala.

Data store peserta dialirkan dan diproses menjadi data peserta dan selanjutnya menjadi laporan daftar peserta selanjutnya di alirkan ke entitas pimpinan/kepala. Data store pelatihan diproses menjadi data pelatihan diproses menjadi laporan daftar pelaksanaan pelatihan selanjutnya di alirkan ke entitas pimpinan/kepala. 


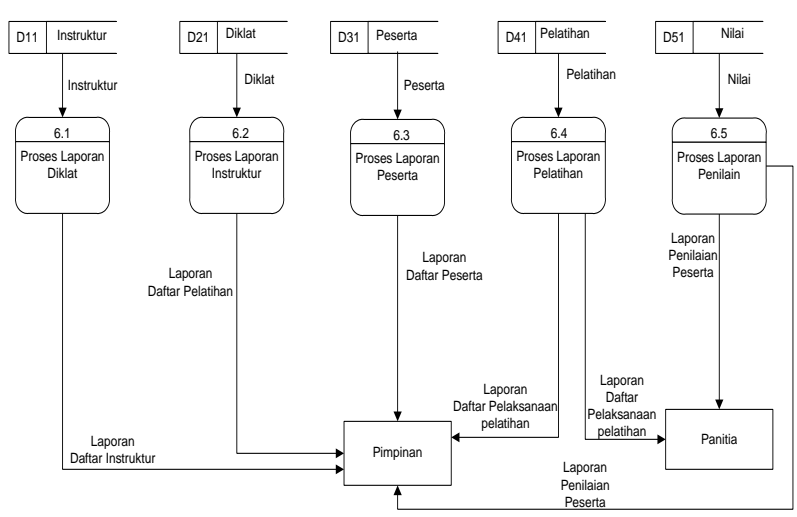

Gambar 6. Data Flow Diagram (DFD) Level 1

\section{IMPLEMENTASI}

1. Tampilan Menu Utama

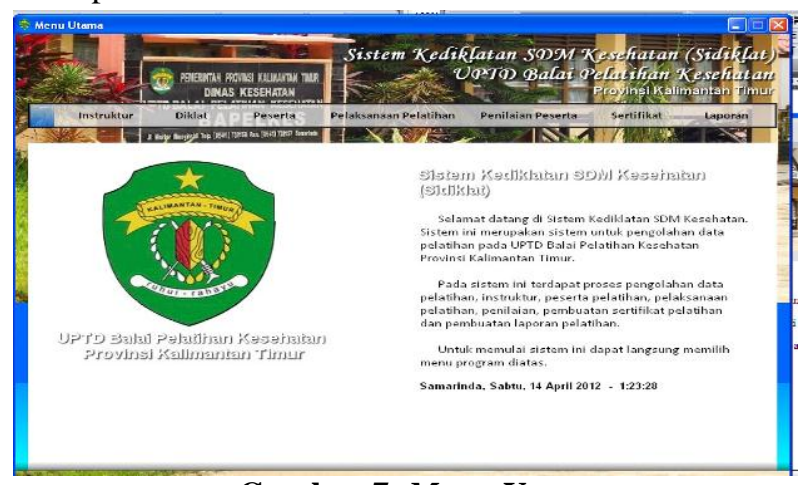

Gambar 7. Menu Utama

merupakan tampilan menu utama Sistem Informasi Kediklatan SDM Kesehatan (Sidiklat) pada UPTD. Balai Pelatihan Kesehatan Provinsi Kalimantan Timur. Pada menu utama tersebut terdapat 7 (tujuh) macam pilihan sistem yaitu:

1. Instruktur, merupakan menu untuk menginput data instruktur/pelatih.

2. Diklat, merupakan menu untuk menginputkan data diklat/kegiatan yang akan di laksanakan

3. Peserta merupakan menu untuk menginput data peserta yang akam mengikuti diklat.

4. Proses Pelaksanaan Pelatihan, merupakan menu untuk memproses pelatihan apa saja yang dilaksanakan.

5. Proses Penilai Peserta, merupakan menu untuk memproses nilai yang didapatkan dari hasil pre tes masing-masing peserta untuk mengetahui sampai dimana kopetensi masing- masing peserta.

6. Sertifikat, merupakan menu untuk mencetak sertifikat peserta yang akan diserahkan kepada masing-masing peserta.

7. Laporan merupakan menu untuk mencetak semua laporan yang meliputi : Laporan daftar instruktur, laporan daftar peserta, laporan personal instruktur, laporan personal peserta, laporan daftar pelatihan, laporan pelaksanaan pelatihan, lapran penilaian peserta dan laporan semua data pelatihan, laporan per bulan dan laporan per tahun.

\section{Tampilan Form Input Data Instruktur}

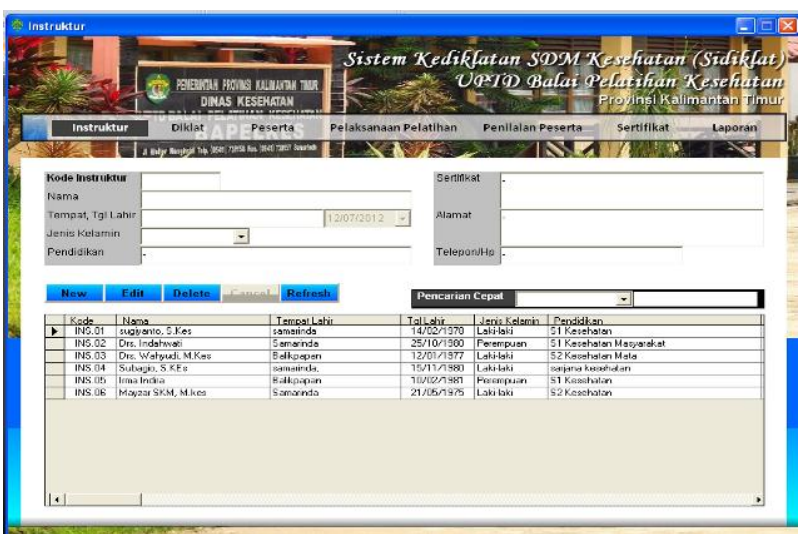

Gambar 8. Form Input Data Instruktur

Merupakan form untuk menginputkan data instruktur/pelatih data yang akan diinput berisikan identitas instruktur/pelatih. Dalam tampilan input data ini terdapat 5 (lima) tombol navigasi yaitu tombol new, edit, delet ,cancel dan Refresh.

Jika pengguna (user) menekan tombol new maka pengguna (user) dapat meginputkan data yang baru. Selanjutnya pengguna (user) dapat save data yang diinput. Jika pengguna (user) menekan tombol delete maka data instruktur akan terhapus. Jika pengguna (user) ingin mengedit ketik salah kolom yang ingin diedit maka kesalahan data yang diinput dapat diperbaiki. Apabila pengguna(user) menekan tombol cancel maka data akan kembali dan tidak ada perubahan. Apabila penggunan (user )menekan tombol refresh maka form yang akan diinput menjadi kosong. Untuk mencari data maka pengguna (user) cukup menekan searching dan mengetik nama yang akan di cari maka akan muncul nama instruktur yang akan dicari.Tampilan

\section{Form Data Diklat}

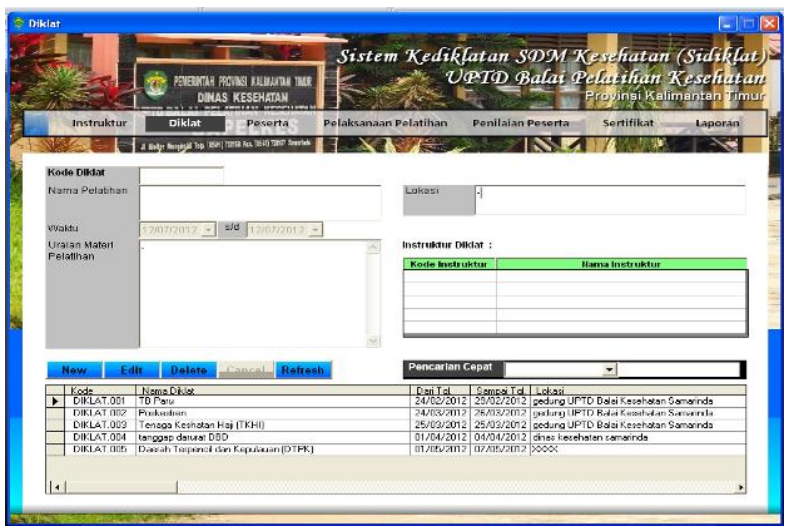

Gambar 9. Form Input Data Diklat

merupakan form diklat untuk menginputkan data diklat yang akan di laksanakan. Data yang akan diinput berisikan kode diklat, nama pelatihan, waktu, uraian materi pelatihan dan lokasi. Dalam tampilan input data ini terdapat 4 (empat) tombol navigasi dan 5 (lima) tombol lainnya yaitu new, edit, delete, cancel dan refresh. 
Jika pengguna (user) menekan tombol new maka pengguna (user) dapat meginputkan data yang baru. Selanjutnya pengguna (user) dapat save data yang diinput. Jika pengguna (user) menekan tombol delete maka data instruktur akan terhapus. Jika pengguna (user) ingin mengedit ketik salah kolom yang ingin diedit maka kesalahan data yang diinput dapat diperbaiki. Apabila pengguna (user) menekan tombol cancel maka data akan kembali dan tidak ada perubahan. Apabila penggunan (user )menekan tombol refresh maka form yang akan diinput menjadi kosong. Untuk mencari data maka pengguna (user) cukup menekan searching dan mengetik nama yang akan di cari maka akan muncul nama diklat yang akan dicari. Untuk nama instruktur yang akan masuk atau mengisi materi pengguna (user) menekan kolom yang ada di form nama instruktur dan akan muncul tombol untuk memilih dan berapa banyak instruktur dalam mengisi materi dalam satu hari.

\section{Tampilan Form Input Data Peserta}

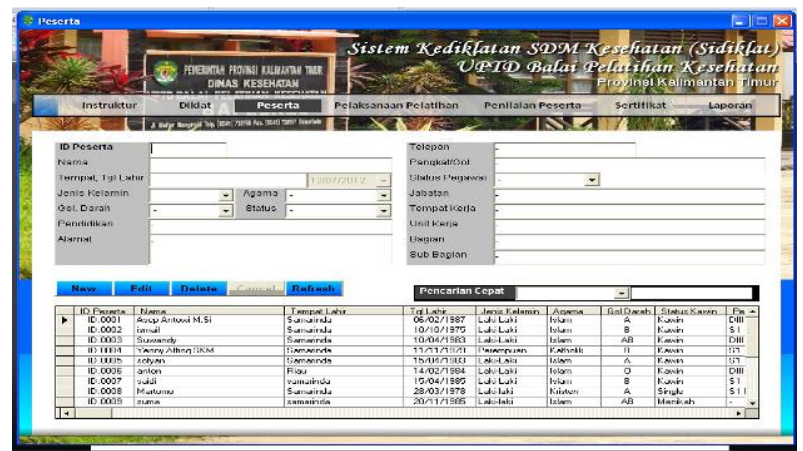

\section{Gambar 10. Form Input Data Permintaan}

merupakan form untuk menginputkan data peserta pelatihan. Inputan datanya berisikan id peserta, nama peserta, tempat tanggal lahir, jenis kelamin, agama, golongan darah status, pendidikan, Alamat, telepon, pangkat/golongan, status pegawai, jabatan, tempat kerja, unit kerja, bagian/bidang, sub bagian/bidang. Jika pengguna (user) menekan tombol new maka pengguna (user) dapat meginputkan data yang baru. Selanjutnya pengguna (user) dapat save data yang diinput. Jika pengguna (user) menekan tombol delete maka data instruktur akan terhapus. Jika pengguna (user) ingin mengedit ketik salah kolom yang ingin diedit maka kesalahan data yang diinput dapat diperbaiki. Apabila pengguna (user) menekan tombol cancel maka data akan kembali dan tidak ada perubahan. Apabila penggunan (user )menekan tombol refresh maka form yang akan diinput menjadi kosong. Untuk mencari data maka pengguna (user) cukup menekan searching dan mengetik nama yang akan dicari.Tampilan Form Input Pemesanan
5. Tampilan Form Input Proses Pelaksanaan Pelatihan

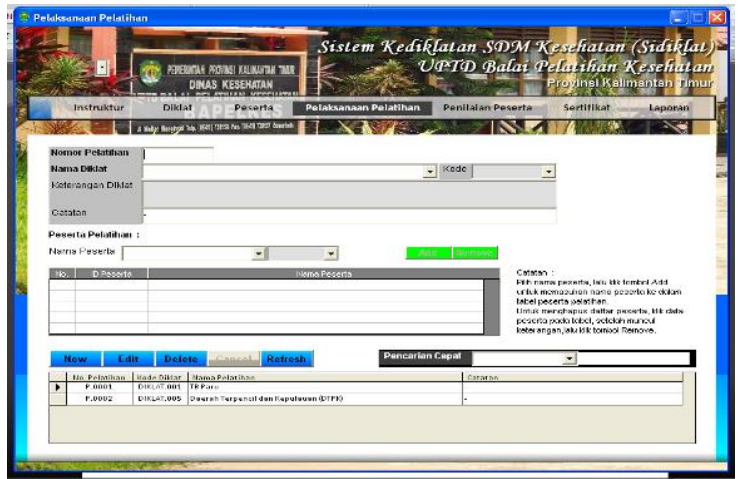

Gambar 11.Form Input Proses Pelaksanaan Pelatihan

merupakan form untuk memproses data pelakasanaan pelatihan. Datanya berisikan nomor pelatihan, nama diklat, kode, keterangan diklat,catatan, Jika pengguna (user) menekan tombol new maka pengguna (user) dapat meginputkan data yang baru. Selanjutnya pengguna (user) dapat save data yang diinput. Jika pengguna (user) menekan tombol delete maka data instruktur akan terhapus. Jika pengguna (user) ingin mengedit ketik salah kolom yang ingin diedit maka kesalahan data yang diinput dapat diperbaiki. Apabila pengguna (user) menekan tombol cancel maka data akan kembali dan tidak ada perubahan. Apabila penggunan (user) menekan tombol refresh maka form yang akan diinput menjadi kosong. Untuk mencari data maka pengguna (user) cukup menekan searching dan mengetik nama yang akan dicari.

\section{Tampilan Form Proeses Penilaian Peserta}

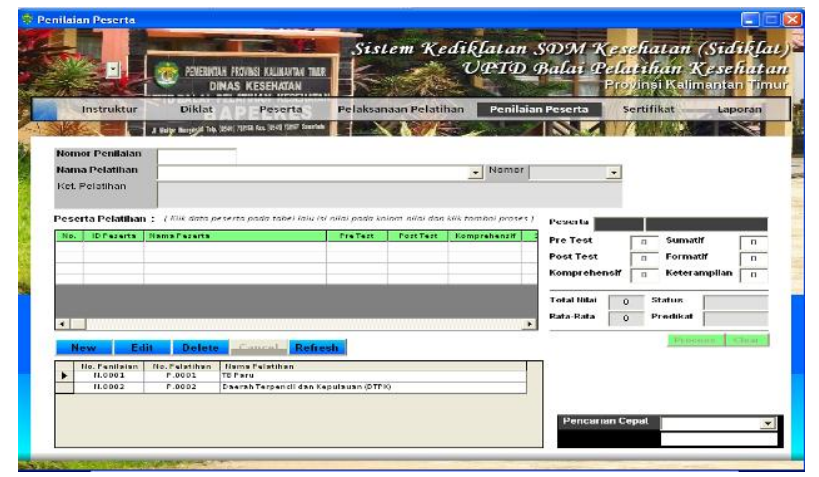

Gambar 12. Form Prose Penilaian Peserta merupakan form untuk memproses data penilaian peserta. Datanya berisikan nomor penilaian, nama pelatihan, nomor, keterangan pelatihan, Jika pengguna (user) menekan tombol new maka pengguna (user) dapat meginputkan data yang baru. Selanjutnya pengguna (user) dapat save data yang diinput. Jika pengguna (user) menekan tombol delete maka data instruktur akan terhapus. Jika pengguna (user) ingin mengedit ketik salah kolom yang ingin diedit maka kesalahan data yang diinput dapat diperbaiki. Apabila pengguna (user) menekan tombol cancel maka data akan kembali dan tidak ada perubahan. Apabila penggunan (user)menekan tombol refresh maka form yang akan diinput menjadi kosong. Untuk mencari 
data maka pengguna (user) cukup menekan searching dan mengetik nama yang akan dicari.

Untuk memasukkan nilai pengguna (user) cukup mengarahkan kursor atau mouse ke nama peserta kemudian kemudian masukkan nilai yang akan diinput. Untuk predikat jika nilai lebih dari 80 maka dinyatakan Sangat Baik dengan predikat nilai A, jika nilai lebih dari 70 maka dinyatakan Baik dengan predikat nilai B, jika nilai lebih dari 60 maka dinyatakan Cukup Baik dengan predikat nilai $\mathrm{C}$, jika nilai lebih dari 50 maka dinyatakan Kurang Baik dengan predikat nilai D, jika nilai kurang dari 50 maka dinyatakan Tidak Baik dengan predikat nilai $\mathrm{E}$.

\section{KESIMPULAN}

1. Dengan adanya Sistem Informasi Kediklatan SDM Kesehatan (Sidiklat) dapat mempersingkat waktu dalam proses pelaporan diklat pada UPTD Balai Pelatihan Kesehatan Provinsi Kalimantan Timur dengan menggunakan pemrograman visual basic 6.0 .

2. Kediklatan SDM Kesehatan (Sdiklat) Pada UPTD Balai Pelatihan Kesehatan dapat tertata dengan baik

3. Sistem Informasi Kedilatan SDM Kesehatan (sidiklat) pada UPTD Balai Pelatihan Kesehatan Provinsi Kalimantan Timur dapat mempermudah proses pembuatan laporan proses Pelaksanaan Pelatihan secara komputerisasi.

\section{SARAN}

1.Sistem ini dapat di kembangkan dalam sistem jaringan sehingga lebih mudah untuk panitia pelaksana dalam mengelola kegiatan pelatihan pada UPTD Balai Pelatihan Kesehatan Provinsi Kalimantan Timur.

2. Sistem Informasi Kediklatan SDM Kesehatan ini dapat digunakan untuk membantu akreditasi pada UPTD. Balai Pelatihan Kesehatan provinsi Kalimantan Timur.

3. Demi keamanan data dan keseragaman data yang diinput, untuk pengembangan selanjutnya dapat dibuatkan format input tersendiri untuk jenis huruf kapital panjang input dalam sebuah field, dan sebagainya.

4. Pemberian sertifikat peserta harus yang dinyatakan lulus sesuai dengan hasil penilaian masingmasing peserta.

\section{DAFTAR PUSTAKA}

Febrian, Jack, 2004. Kamus Komputer \& Teknologi Informasi, Bandung : Informatika

Jogiyanto. H.M, 2005. Analisa dan Sistem Informasi: Pendekatan Terstruktur Teori dan Praktek Aplikasi Bisnis, Yogyakarta : Andi Offset.
Jogiyanto. HM, 2008, Analisis dan Desain Sistem Informasi Edisi Ketiga, Cetakan Kedua, Yogyakarta : Andi Offset.

Jogiyanto, 2001, Analisis dan desain system informasi, Yogyakarta: Andi Offset.

Kadir, Abdul, 2007, Konsep dan Tuntunan Praktis Basis Data, Yogyakarta: Andi Offset.

Kadir, Abdul, 2009, Mudah Mempelajari Database Mysql, Yogyakarta: Andi Offset.

Kadir, Abdul, 2004, Aplikasi Pemograman Database dengan Visual Basic 6.0 dan Crystal Report, Yogyakarta : Andi Offset.

Leman., 2004. Metodologi Pengembangan Sistem Informasi, Jakarta : PT. Elekmedia Komputindo.

Lukman, Ali, 2004, Kamus Besar Bahasa Indonesia, Jakarta : Balai Pustaka.

Martino, 2003, Sistem Informasi dan Teknologi Komunikasi, Jakarta : PT. Elekmedia Komputindo.

Moekijat, 2001. Sistem Informasi Komputer. Jakarta: PT Elex Media Komputindo.

Oetomo, BSD, 2002. Perancangan dan Pembangunan Sistem Informasi, Jakarta : Balai Pustaka.

Pressman, Roger S, 2004, Rekayasa Perangkat Lunak, Yogyakarta : andi Offset.

Scott, George M., 2002, Prinsip-prinsip Sistem Informasi Manajemen, Cetakan Keenam, Jakarta : PT. Raja Grafindo Persada.

Subari \& Yuswanto, 2008, Penduang Lengkap Pemograman Visual Basic 6.0, jakarta : Cerdas Pustaka Publisher.

Supriyanto, Aji, 2005. Pengantar Teknologi Informasi, Semarang : Salemba Infotek.

Squire. E, 2002. Mendesain Sistem. Jakarta : PT Pustaka Binaman Pressindo.

Witarto, 2004. Sistem Informasi Manajemen Jilid Satu Edisi Ke-7. Jakarta : Prenhallindo.

Waluya, 2005, Pengantar Sistem Informasi Manajemen, Jakarta : Erlangga. 